\title{
IMPLEMENTASI UNDANG-UNDANG ARBITRASE TERHADAP PELAKSANAAN PUTUSAN ARBITRASE INTERNASIONAL DI INDONESIA (MEMASUKI 12 TAHUN USIA UNDANG-UNDANG ARBITRASE)
}

\author{
Mutiara Hikmah ${ }^{1}$
}

\begin{abstract}
Law No. 30 of 1999 concerning The arbitration and Alternative Dispute Resolution have been arranged on enforcement of international arbitral awards in Indonesia. Before the enactment of the arbitration Law, primary before The Supreme Court produce Regulation No.1 Year 1990 concerning Procedures of Foreign Arbitral Award Implementation (the Regulation), there were still impediments to the stakeholders in implementing the international arbitral award in Indonesia. During that time, the Indonesian Supreme Court as the highest judicial body argues that the international arbitral award is not implementable in Indonesia. Soon after the issuance of the Regulation, the foreign arbitral award is implementable due to the clarity in the Indonesian Procedure Laws concerning it. In order to arrange in the national of law, on 12 August 1999 the Arbitration Law was enacted which regulate on how international arbitral award implemented. This paper will explore how the implementation of the law of arbitration when this law will come to 12 years old.
\end{abstract}

Keywords: law of arbitration, implementation, international arbitral awards

\begin{abstract}
Abstrak
Undang-Undang Nomor 30 Tahun 1999 tentang The arbitrase dan Resolusi Sengketa Alternatif telah diatur pada penegakan putusan arbitrase internasional di Indonesia. Sebelum berlakunya UU arbitrase, primer sebelum Mahkamah Agung menghasilkan Peraturan No.1 Tahun 1990 tentang Tata Cara Pelaksanaan Penghargaan Arbitrase Asing (Peraturan), masih ada halangan kepada para pemangku kepentingan dalam melaksanakan putusan arbitrase internasional di Indonesia. Selama waktu itu, Mahkamah Agung Indonesia sebagai badan tertinggi peradilan berpendapat bahwa putusan arbitrase internasional tidak
\end{abstract} muti_h@ui.ac.id

1 Penulis adalah Staf Pengajar FHUI. Alamat kontak: mtiara90@yahoo.com dan 
diimplementasikan di Indonesia. Segera setelah penerbitan Peraturan, putusan arbitrase asing dapat diterapkan karena kejelasan dalam Hukum Prosedur Indonesia tentang hal itu. Dalam rangka untuk mengatur dalam hukum nasional, pada tanggal 12 Agustus 1999 UU Arbitrase diundangkan yang mengatur tentang bagaimana putusan arbitrase internasional yang dilaksanakan. Tulisan ini akan membahas bagaimana pelaksanaan hukum arbitrase saat undang-undang ini akan datang ke 12 tahun.

Kata kunci: hukum arbitrase, pelaksanaan, arbitrase penghargaan internasional

\section{Latar Belakang}

Indonesia telah memiliki Undang Undang tentang Arbitrase Dan Alternatif Penyelesaian Sengketa (selanjutnya disingkat dengan UU Arbitrase) sejak 12 Agustus 1999. Di dalam Pasal 65 sampai dengan Pasal 69 undang-undang tersebut mengatur tentang pelaksanaan putusan arbitrase internasional. ${ }^{2}$

Pada masa sebelum berlakunya UU Arbitrase, terutama pada saat belum dikeluarkannya Peraturan Mahkamah Agung mengenai pelaksanaan putusan arbirase asing, masih terdapat hambatan bagi pengusaha asing dalam hal pelaksanaan putusan arbitrase internasional di Indonesia. Hal ini dapat dipelajari dari sejarah mengenai pelaksanaan putusan arbitrase internasional di Indonesia.

Jika mempelajari sejarahnya, pelaksanaan putusan arbitrase internasional di Indonesia dikenal sejak jaman Pemerintahan Hindia Belanda, tepatnya pada tahun 1933 ketika Pemerintah Hindia Belanda meratifikasi Konvensi Jenewa 1927, yaitu Geneva Convention on The Execution of Foreign Arbitral Awards of 1927 (Konvensi tentang Pelaksanaan Putusan Arbitrase Asing). Pengumuman tentang ratifikasi

2 Istilah "arbitrase internasional" digunakan oleh peneliti, karena mengacu pada UndangUndang No. 30 Tahun 1999 tentang Arbitrase dan Alternatif Penyelesaian Sengketa pada Bab VI bagian kedua Pasal 65 - 69 tentang arbitrase internasional. Sedangkan menurut Konvensi New York 1958 istilah yang digunakan adalah "árbitrase asing", sebagai terjemahan dari New York Convention On the Recognition and Enforcement of Foreign Arbitral Awards. Istilah "arbitrase asing" juga digunakan dalam Peraturan Mahkamah Agung RI No. 1 Tahun 1990 Tentang Tata Cara Pelaksanaan Putusan Arbitrase Asing Mahkamah Agung RI. Istilah lain yang digunakan oleh Sudargo Gautama, yaitu "arbitrase luar negeri" (Lihat: Sudargo Gautama (a), Arbitrase Luar Negeri dan Pemakaian Hukum Indonesia, Bandung: PT Citra Aditya Bakti, 2004, hal. 1). Istilah "arbitrase luar negeri" juga digunakan oleh Erman Rajagukguk (Lihat: Erman Rajagukguk, Arbitrase Dalam Putusan Pengadilan, (Jakarta: Chandra Pratama, 2001), hal. 64). Istilah Arbitrase Asing juga digunakan dalam hal pencatatan Pendaftaran Putusan Arbitrase Asing di Pengadilan Negeri Jakarta Pusat sampai saat ini. 
konvensi tersebut tertuang di dalam Staatsblad 1933 No. 131 (mulai berlaku pada tanggal 28 April 1933) dan dalam Staatsblad tersebut dinyatakan bahwa Konvensi Jenewa tanggal 26 September 1927 berlaku untuk Hindia Belanda ${ }^{3}$. Berdasarkan Konvensi Jenewa tersebut, suatu putusan arbitrase internasional dapat dilaksanakan di negara peserta konvensi lainnya apabila putusan tersebut memenuhi beberapa persyaratan yang diatur di dalam Pasal 1 ayat (1). ${ }^{4}$ Selain itu, Indonesia telah menjadi anggota Konvensi New York 1958 melalui Keputusan Presiden RI (Keppres) No. 34 Tahun 1981 dan diterbitkan dalam Lembaran Negara RI tahun 1981 No. $40 .{ }^{5}$ Dengan ikut sertanya negara Indonesia dalam Konvensi New York 1958, maka Indonesia terikat pada ketentuan-ketentuan yang terdapat di dalam konvensi tersebut mengenai pengakuan dan pelaksanaan putusan arbitrase internasional.

Pada awalnya, sikap Pemerintah Indonesia (dalam hal ini Mahkamah Agung RI), tidak mengakui pelaksanaan putusan arbitrase internasional. Akan tetapi, kesadaran bahwa negara Indonesia akan terus tumbuh menjadi bagian dari aktivitas bisnis dunia, maka Pemerintah Indonesia harus memikirkan langkah ke depan untuk dapat mengakui dan melaksanakan putusan-putusan arbitrase internasional. Khususnya dalam upaya menarik perhatian para investor untuk memilih Indonesia sebagai tempat utama dalam aktivitas investasinya. Maka negara Indonesia harus membuka diri untuk mengikuti trend penyelesaian sengketa melalui arbitrase yang diikuti dengan pengakuan dan pelaksanaan putusan arbitrase internasionalnya. ${ }^{6}$

${ }^{3}$ Sudargo Gautama (b), Soal-soal Aktual Hukum Perdata Internasional, (Bandung: Alumni, 1981), hal. 209 - 210. Juga lihat: Sudargo Gautama (c), Kontrak Dagang Internasional, cetakan kedua, (Bandung: Alumni, 1983), hal. 55. lain:

${ }^{4}$ Beberapa persyaratan yang terdapat di dalam Pasal 1 ayat(1) Konvensi Jenewa 1927, antara

1. Putusan arbitrase tersebut dibuat berdasarkan perjanjian arbitrase yang berlaku pada perjanjian tersebut Protokol Jenewa 1923;

2. Putusan arbitrase tersebut dibuat di salah satu negara peserta konvensi;

3. Para pihak dalam putusan tersebut tunduk pada jurisdiksi dari salah satu negara peserta konvensi.

${ }^{5}$ Keanggotaan Indonesia secara resmi pada konvensi terhitung sejak 7 Oktober 1981. Ada 2 pensyaratan (reservation) yang ditentukan oleh Pemerintah Indonesia sewaktu meratifikasi Konvesi New York 1958, yaitu: reciprocity reservation dan commercial reservation. Lihat: Sudargo Gautama (b), Op. Cit., hal. 214.

${ }^{6}$ Ricardo Simanjuntak, Konflik Yurisdiksi Antara Arbitrase Dan Pengadilan Negeri, dalam Jurnal Hukum Bisnis (Vol. 21, Oktober-November 2002), hal. 85. 
Apalagi jika melihat tendensi yang terjadi pada akhir-akhir ini, dalam kontrakkontrak yang ditanda tangani oleh Badan Usaha Milik Negara (BUMN) atau Perusahaan Negara di satu pihak dengan pihak asing, baik dalam bentuk Kerja Sama Operasi(KSO)/Joint Operation Contract (JOC) atau lain-lain usaha bersama dan perjanjian yang bersifat "internasional", dipakai klausul mengenai penyelesaian sengketa melalui arbitrase dan umumnya arbitrase ditentukan akan dilangsungkan di luar negeri ${ }^{7}$. Walaupun dalam kontrak ditentukan bahwa hukum Indonesia yang dipilih untuk menyelesaikan sengketa, namun pelaksanaan pemeriksaan arbitrasenya dilangsungkan di luar negeri. Jika pelaksanaan pemeriksaan dan proses arbitrase berlangsung di luar negeri, ketika putusan arbitrase diucapkan dan pihak yang kalah dalam proses tersebut adalah pihak dari Indonesia, maka hal ini akan berakibat pihak yang menang dalam proses arbitrase tersebut memohon pelaksanaan putusan arbitrase internasional tersebut di Indonesia.

\section{Pengaturan mengenai Pelaksanaan Putusan Arbitrase Internasional dalam Undang-Undang Arbitrase}

\section{Definisi Putusan Arbitrase Internasional}

UU Arbitrase di dalam Pasal 1 ayat (9) memberikan definisi putusan arbitrase internasional yaitu: ${ }^{8}$

Putusan arbitrase internasional adalah putusan yang dijatuhkan oleh suatu lembaga arbitrase atau arbitrator perorangan di luar wilayah hukum Republik Indonesia, atau putusan suatu lembaga arbitrase atau arbitrator perorangan yang menurut ketentuan hukum Republik Indonesia dianggap sebagai putusan arbitrase internasional.

Menurut pendapat peneliti, dari definisi tersebut maka dapat dikategorikan beberapa putusan arbitrase internasional yang masuk dalam ruang lingkup Pasal 1 ayat (9) UU Arbitrase, antara lain:

${ }^{7}$ Sudargo Gautama (a), Op. Cit., hal. 1.

${ }^{8}$ Indonesia. Undang-Undang tentang Arbitrase Dan Alternatif Penyelesaian Sengketa, UU No.30 Tahun 1999, Pasal 1 ayat (9). 
1) Bila putusan tersebut dijatuhkan oleh suatu lembaga arbitrase atau arbitrator perorangan, di luar wilayah Hukum RI; (Sebagai contoh dari ruang lingkup ini adalah putusan-putusan arbitrase yang diucapkan di luar negeri dari suatu lembaga arbitrase, misalnya putusan arbitrase dari ICC, ICSID, SIAC, dan sebagainya. Selain itu, putusan arbitrase dari luar negeri yang diucapkan oleh arbitrator perorangan, juga dapat dimintakan pelaksanaannya di Indonesia, asalkan putusan tersebut berasal dari negara sesama peserta Konvensi New York 1958).

2) Bila putusan tersebut dijatuhkan oleh suatu lembaga arbitrase atau arbitrator perorangan yang menurut ketentuan Hukum Republik Indonesia dianggap sebagai suatu putusan arbitrase internasional. Contohnya adalah putusan arbitrase yang diputuskan oleh lembaga BANI di Jakarta. Jika putusan tersebut terdiri dari para pihak yang berbeda kewarganegaraan, atau memiliki domisili yang berbeda, atau para pihak memilih hukum asing yang berbeda atau hukum salah satu dari pihak yang melakukan perjanjian arbitrase. Contoh lain apabila para pihak adalah perusahaan Indonesia dan memilih tempat arbitrase di Jakarta namun memilih rulesnya dari lembaga arbitrase internasional ICC Paris. ${ }^{9}$

Jika mempelajari frase pertama Pasal 1 ayat (9) UU Arbitrase, yaitu: "Bila putusan tersebut dijatuhkan oleh suatu lembaga arbitrase atau arbitrator perorangan, di luar wilayah Hukum RI, ..." maka yang termasuk ke dalam kategori ini adalah putusan-putusan arbitrase yang berasal dari lembaga arbitrase di luar negeri, juga putusan-putusan arbitrase yang berasal dari arbitrator perorangan di luar negeri atau di luar wilayah negara RI. Penekanan pada frase ini adalah asas teritorial dari suatu putusan arbitrase, yaitu berasal dari luar teritori wilayah negara RI.

Namun akan menjadi luas pengertiannya, bila mempelajari frase kedua Pasal 1 ayat (9) UU Arbitrase, yaitu "...bila putusan tersebut dijatuhkan oleh suatu lembaga arbitrase atau arbitrator perorangan yang menurut ketentuan Hukum Republik Indonesia dianggap sebagai suatu putusan arbitrase internasional". Maka akan banyak sekali kriteria yang dapat masuk ke dalam

${ }^{9}$ Terlihat pada kasus PT Pertamina dan PT Pertamina EP vs. PT Lirik Petroleum (Putusan No.01/Pembatalan Arbitrase/2009/PN.JKT.PST tanggal 31 Agustus 2009). Dalam perjanjian dengan klausul arbitrasenya, para pihak yang merupakan Badan Hukum Indonesia memilih tempat arbitrase di Jakarta dengan rulesnya dari ICC Paris. 
pengertian tersebut. Namun hal ini kembali kepada Hakim sebagai pemutus perkara, bagaimana penafsirannya terhadap frase-frase dari Pasal 1 ayat (9) tersebut. Perumusan frase kedua ini, membuat aparat penegak hukum harus lebih cermat dalam menafsirkan sistem hukum di Indonesia yang mengkaji permasalahan putusan arbitrase Internasional.

Jika mempelajari ketentuan Hukum RI yang membahas mengenai putusan arbitrase internasional, maka teori-teori yang digunakan adalah teori-teori Hukum Perdata Internasional/HPI. HPI dirumuskan sebagai berikut: ${ }^{10}$

Keseluruhan peraturan dan keputusan hukum yang menunjukan stelsel hukum manakah yang belaku atau apakah yang merupakan hukum, jika hubungan-hubungan dan peristiwa-peristiwa antara warga (warga) negara pada satu waktu tertentu memperlihatkan titik-titik pertalian dengan stelsel-stelsel dan kaidah-kaidah hukum dari dua atau lebih negara, yang berbeda dalam lingkunganlingkungan kuasa tempat.

\section{Syarat-syarat Putusan Arbitrase Internasional Dapat Dilaksanakan}

Hal penting yang berhubungan dengan pelaksanaan putusan arbitrase internasional adalah mengenai syarat-syarat yang harus dipenuhi agar suatu putusan arbitrase internasional dapat dilaksanakan di Indonesia. Mengenai syarat-syarat ini, diatur di dalam Pasal 66 yang menyebutkan antara lain:

1) Putusan Arbitrase Internasional dijatuhkan oleh arbitrator atau majelis arbitrase di suatu negara yang dengan negara Indonesia terikat pada perjanjian, baik secara bilateral maupun multilateral, mengenai pengakuan dan pelaksanaan putusan arbitrase internasional;

Syarat resiprositas merupakan salah satu hal yang penting dalam pemberian eksekuatur terhadap putusan arbitrase internasional. Dalam hal ini, pengadilan harus meneliti apakah negara di tempat mana putusan dijatuhkan, mempunyai hubungan bilateral atau multilateral maupun sama-sama terikat dalam suatu konvesi internasional dengan Negara Indonesia, periha pengakuan serta pelaksanaan putusan arbitrase internasional. Maksudnya, apakah ada ikatan saling timbal balik antara negara yang menjatuhkan putusan arbitrase dengan negara

${ }^{10}$ Sudargo Gautama (d), Pengantar Hukum Perdata Internasional Indonesia, cetakan kelima (Bandung: Binacipta, 1987), hal. 21. 
Indonesia, perihal pengakuan dan pelaksanaan putusan arbitrase internasional. ${ }^{11}$

Mengenai syarat resiprositas, putusan arbitrase internasional yang dapat dilaksanakan di Indonesia adalah putusan arbitrase yang berasal dari sesama anggota Konvensi New York 1958 atau bukan dari negara peserta konvensi, tetapi ada perjanjian bilateral yang telah dibuat antara negara Indonesia dengan negara bukan anggota peserta Konvensi New York 1958 tersebut. Mengenai syarat untuk memenuhi asas resiprositas ini, bukti otentik yang diperlukan adalah surat keterangan dari Perwakilan Negara RI dimana putusan arbitrase tersebut berasal.

Sikap negara Indonesia yang berpegang teguh pada asas resiprositas mengenai pengakuan dan pelaksanaan putusan arbitrase internasional, merupakan landasan atas prinsip kedaulatan negara dan kedaulatan hukum maupun kedaulatan pengadilan dan bangsa Indonesia. Asas ini berpegang teguh pada prinsip saling menghormati diantara sesama bangsa dan negara lain. Negara kita akan menghormati negara lain apabila secara timbal balik negara ain juga menghormati negara kita. Negara akan mengakui dan melaksanakan putusan arbitrase yang dijatuhkan di suatu negara, apabila secara timbal balik negara tersebut bersedia pula mengakui dan melaksanakan putusan arbitrase yang dijatuhkan di Indonesia. ${ }^{12}$

Pencantuman asas resiprositas pada Pasal 66 butir (a) UU Arbirase (diatur sebelumnya di dalam Perma Pasal 3 ayat (1), berdasarkan pada nilai-nilai hukum internasional yang secara universal telah berlaku sejak dahulu dalam semua bidang kehidupan antar bangsa. Asas ini terjalin meliputi semua aspek, termasuk aspek politik, ekonomi, sosial, budaya, keamanan, diplomatik, dan termasuk bidang hukum. ${ }^{13}$

Atas asas saling menghargai dan menghormati antar sesama bangsa, Konvensi New York 1958 pun mempertahankan asas resiprositas sebagai salah satu syarat untuk mengakui dan melaksanakan putusan arbitrase internasional. Pasal 1 ayat (3) menyebutkan"any state may

${ }^{11}$ M.Yahya Harahap, Arbitrase.(Jakarta: Sinar Grafika,2004), hal. 344.

${ }^{12}$ Ibid.

${ }^{13}$ Ibid., hal. 345. 
on the basis of reciprocity declare that will apply the Convention to recognition and enforcement of awards made only in territory of another Contracting State. (Terjemahan bebas dari peneliti: Setiap negara boleh menyatakan berlakunya asas resiprositas akan berlaku terhadap pengakuan dan pelaksanaan putusan yang dibuat hanya di wilayah negara peserta konvensi yang lain). Kenyataan menunjukan bahwa semua negara anggota peserta Konvensi New York 1958 telah mendeklarasikan asas resiprositas pada saat meratifikasi atau mengesahkan konvensi. Hal tersebut dapat diketahui pada catatan lampiran konvensi yang dibuat pada tahun $1983 .{ }^{14}$

Sikap ini diikuti Pemerintah RI pada saat pengesahan konvensi pada tahun 1981. Dalam lampiran Keppres No. 34 Tahun 1981 tanggal 5 Agustus 1981, telah dikeluarkan deklarasi yang menegaskan, menunjuk atau sesuai dengan ketentuan Pasal I ayat (3) Konvensi:'the Government of the Republic of Indonesia declares that its will apply the Convention on the basis reciprocity". (Pemerintah RI mendeklarasikan bahwa akan menerapkan konvensi ini berdasarkan asas resiprositas). Dengan demikian, secara mutlak pengadilan di Indonesia harus menolak pemberian eksekuatur putusan arbitrase internasional yang dijatuhkan di suatu negara yang tidak mempunyai ikatan hubungan bilateral atau multilateral dengan negara RI di bidang arbitrase. $^{15}$

Jika dihubungkan dengan teori umum HPI, asas resiprositas merupakan bagian dari pembahasan Teori Timbal balik dan Pembalasan. Timbal balik dimaksudkan suatu keadaan yang dikehendaki, sedangkan pembalasan merupakan cara untuk mencapai keadaan tersebut. Timbal balik mempunyai lingkungan berlaku yang umum, yakni diberlakukan terhadap semua negara asing. Pembalasan dibatasi hanya pada negara tertentu yang secara melawan hukum telah melakukan perbuatan yang harus dibalas. Timbal balik menghendaki terlebih dahulu pembuktian dari adanya persamaan oleh negara asing yang bersangkutan dan baru setelah itu diberikan persamaan. Pembalasan lebih dahulu terjadi persamaan, yang dihentikan apabila dibuktikan kelak adanya perlakuan yang tidak sama oleh negara asing

\footnotetext{
${ }^{14}$ Ibid.

${ }^{15}$ Ibid.
} 
yang bersangkutan. ${ }^{16}$ Contoh pemakaian timbal balik dan pembalasan secara bersamaan, dapat dilihat pada Hukum Acara Perdata Jerman Par.114 sub 2 Z.P.O. tentang kemungkinan untuk berperkara bebas biaya. Bunyi pasal tersebut "Orang asing tidak diberikan hak berperkara bebas biaya apabila orang Jerman di negara asing yang bersangkutan tidak diberikan hak serupa". ${ }^{17}$

Asas timbal balik dapat dibedakan secara formal dan materiil. Timbal balik formal, berarti orang asing akan diperlakukan sama dengan warga sendiri dengan syarat bahwa di negara orang asing bersangkutan warga negara sendiripun diperlakukan demikian. Pada timbal balik ini kita tidak tahu secara pasti apa yang akan menjadi perlakuan dalam tiap-tiap negara. Perlakuan ini disebut juga dengan istilah timbal balik abstrak. Ada 2 bentuk Timbal Balik Formal, yaitu: ${ }^{18}$

1. Asimilasi dengan Warga Negara/National Treatment; ${ }^{19}$

2. Klausula bangsa yang paling diutamakan/The Most Favored $\operatorname{Nation}(M F N)^{20}$.

Timbal Balik Materiil, merupakan perlakuan sama secara timbal balik ini berlangsung menurut proses "ada ubi ada talas, ada budi ada balas". Contoh dalam hukum kontrak perdata adanya klausul terkenal sebagai "exceptio non adimpleti contractus". ${ }^{2 l}$ Beberapa contoh

${ }^{16}$ Sudargo Gautama(e), Hukum Perdata Internasional Indonesia, jilid II bagian 5, buku keenam, (Bandung: Penerbit Alumni, 1998), hal. 146.

${ }^{17}$ Ibid., hal. 147.

${ }^{18}$ Ibid., hal. 149.

${ }^{19}$ Suatu negara dapat menentukan bahwa orang asing akan memperoleh perlakuan yang sama seperti warga negara sendiri. Misalnya dalam suatu perjanjian antara RI dan Filipina, RI dan Thailand. Contoh lain: Pasal 3 AB, Pasal 33 ABGBG Austraia.

20 Warga negara dalam negara bersangkutan akan memperoleh perlakuan yang tidak mengurangi perlakuan yang diberikan kepada warga negara suatu negara lain oleh negara yang menandatangani suatu perjanjian. Contoh: Pasal 1 GATT.

${ }^{21}$ Artinya: tangkisan dengan mengemukakan bahwa pihak lawannya juga tidak melakukan kewajibannya yang timbul dari persetujuan yang timbal balik. Lihat: S. Adiwinata, Istilah Hukum, Latin-Indonesia, cetakan pertama, (Jakarta: PT Intermasa, 1977), hal. 42. 
timbal balik materiil antara lain, Pasal I ayat (3) Konvensi New York 1958 dan Pasal 66 butir (a) UU Arbitrase.

2) Putusan Arbitrase Internasional termasuk dalam ruang lingkup hukum perdagangan;

Syarat kedua yang harus dipenuhi dalam hal pelaksanaan putusan arbitrase internasional di Indonesia adalah ruang lingkup hukum dagang. Untuk menentukan apakah suatu perkara yang terdapat dalam putusan arbitrase termasuk atau tidak dalam ruang lingkup hukum dagang, berpedoman pada ketentuan sistem tata hukum Indonesia. Bukan berpedoman pada sistem tata hukum negara tempat dimana putusan dijatuhkan.

Ketentuan pasal ini, merupakan penegasan ketentuan dalam Pasal I ayat (3) Konvensi New York 1958, yang memberikan kesempatan pembatasan oleh negara peserta konvensi. Hal ini dapat dibaca dalam kalimat akhir pasal tersebut yang berbunyi "It may also declare that its will apply the Convention only to defferences arising out of legal relationships whether contractual or not, which are considered as commercial under the national law of the State making such declaration". (Terjemahan bebas dari peneliti: Juga dapat dideklarasikan bahwa konvensi ini akan berlaku pada perbedaan yang timbul dari hubungan hukum yang bersifat kontraktual atau tidak, yang dianggap sebagai hukum dagang menurut huum nasional negara yang melakukan deklarasi).

Dari deklarasi tersebut, putusan arbitrase internasional yang dapat diakui dan dilaksanakan oleh Pengadilan Indonesia hanya putusan arbitrase yang menyangkut persengketaan yang timbul dalam bidang hukum dagang menurut hukum Indonesia. Dalam bagian penjelasan Pasal 66 butir (b) UU Arbitrase, ruang lingkup hukum perdagangan ini adalah kegiatan-kegiatan antara lain bidang:

- perniagaan;

- perbankan;

- keuangan;

- penanaman modal;

- $\quad$ industri; dan

- hak kekayaan intelektual

Jika mengkaji bagian penjelasan Pasal 66 butir (b) tersebut, maka masih ada beberapa kegiatan perdagangan yang belum termasuk 
dalam perumusan ruang lingkup kegiatan perdagangan. Padahal secara luas, saat ini yang juga termasuk dalam lingkup perdagangan semakin bertambah karena pengaruh nilai-nilai globalisasi maupun kebiasaankebiasaan yang ada diatur asas-asasnya dalam Hukum Dagang Indonesia maupun dalam asas-asas hukum perjanjian. ${ }^{22}$ Beberapa contoh yang dapat diberikan disini adalah kegiatan leasing (sewa guna usaha), serta franchise. ${ }^{23}$

Dengan demikian, apabila sengketa dalam perjanjian leasing dengan memilih forum arbitrase di luar wilayah negara Indonesia, tidaklah pada tempatnya jika Pengadilan menolak untuk melaksanakan putusan arbitrase internasional tersebut dengan alasan leasing tidak dikenal dalam Hukum Dagang Indonesia dan tidak pula diatur di dalam UU Arbitrase. $^{24}$

3) Putusan Arbitrase Internasional tidak bertentangan dengan ketertiban umum;

Asas Ketertiban Umum sebagai dasar atas penolakan pelaksanaan putusan arbitrase internasional, merupakan ketentuan yang berlaku umum di berbagai negara. Hal ini juga diatur di dalam Konvensi New York 1958 Pasal V ayat (2) butir (b) $)^{25}$ jo. Pasal 1 butir (e ) Konvensi Jenewa $1927 .^{26}$ Jika mempelajari sistematika pasal-pasal dalam Konvensi New York 1958, terdapat satu pasal khusus yang mengatur tentang penolakan pengakuan dan pelaksanaan putusan arbitrase

${ }^{22}$ M.Yahya Harahap, Op. Cit., hal. 346.

${ }^{23}$ Ibid., hal. 347.

${ }^{24}$ Ibid., hal. 346.

${ }^{25}$ Bunyi ketentuan Pasal V ayat (2) butir (e) tersebut adalah:

2. Recognition and enforcement of an arbitral award may also be refused if the competent authority in the country where recognition and enforcement is sought finds that:

(e) The recognition or enforcement of the award would be contrary of the public policy of that country.

${ }^{26}$ Bunyi ketentuan Pasal 1 butir (e) tersebut adalah:

To obtain such recognition or enforcement, it shall, further, be necessary:

(e) That the recognition or enforcement of the award is not contrary to the public policy or to the principles of the law of the country in which it is sought to be relied upon. 
internasional. Intinya adalah bahwa Konvensi New York 1958 memberi kesempatan untuk melakukan penolakan putusan arbitrase internasional, sedangkan pembatalan putusan arbitrase internasonal tidak diatur. Salah satu alasan yang dapat dijadikan dasar untuk menolak pelaksanaan putusan arbitrase internasional adalah bertentangan dengan ketertiban umum. ${ }^{27}$

UU Arbitrase tidak memberikan penjelasan tentang apa saja yang termasuk ke dalam ruang lingkup ketertiban umum. Dengan demikian, akan bisa terjadi berbagai penafsiran mengenai apa saja yang dikategorikan sebagai pelanggaran ketertiban umum. Hal ini berbeda dengan bunyi aturan dalam Pasal 4 ayat (2) Perma, dinyatakan agak jelas lagi, yaitu: "Eksekuatur tidak akan diberikan apabila putusan arbitrase asing itu nyata-nyata bertentangan dengan sensi-sendi asasi dari seluruh sistem hukum dan masyarakat di Indonesia (ketertiban umum)"(cetak tebal dari peneliti). Namun bunyi pasal tersebut juga memerlukan penafsiran yang cermat dari Pengadilan untuk memasukan kategori mana sajakah yang termasuk ke dalam sendi-sendi asasi dari seluruh sistem hukum dan masyarakat di Indonesia.

Ketertiban umum merupakan alasan terbanyak yang digunakan oleh hakim, baik tingkat pengadilan maupun tingkat Mahkamah Agung dalam hal penolakan pelaksanaan putusan arbitrase internasional. Hal ini tidak hanya terjadi di Indonesia, tetapi juga di berbagai negara. Bahkan, permohonan pembatalan putusan arbitrase internasional pun menggunakan alasan ketertiban umum sebagai salah satu dasar yang dijadikan alasan oleh pihak yang kalah dalam putusan arbitrase. ${ }^{28}$ Dalam membahas teori-teori umum HPI, Teori Ketertiban Umum merupakan salah satu bahasan yang penting. Pentingnya teori ini, oleh Mancini digambarkan bahwa Ketertiban Umum merupakan salah satu dari tiga rukun seluruh gedung HPI selain Prinsip Nasionalitas dan

${ }^{27}$ M.Yahya Harahap, Op. Cit., hal. 349.

${ }^{28} \mathrm{Hal}$ ini dapat dilihat pada waktu sengketa antara $\mathrm{KBC}$ dengan PT Pertamina. Majelis Hakim Pengadilan Negeri Jakarta Pusat pun menyatakan bahwa putusan arbitrase internasional asal Swiss telah melanggar ketertiban umum, karena tidak menggunakan hukum Indonesia sebagai hukum yang dipilh oleh para pihak dalam klausul pilihan hukum. Lihat: Sudargo Gautama(a), Op. Cit., hal. 50. 
Pilihan Hukum. ${ }^{29}$ Mengenai pengertian ketertiban umum, tidak ada definisi khusus mengenai hal ini dalam peraturan tertulis. Inti dari konsep ketertiban umum adalah pengesampingan berlakunya kaidah hukum asing yang seharusnya berlaku menurut hukum sang hakim karena bertentangan dengan sendi-sendi asasi hukum sang hakim. ${ }^{30}$ Fungsinya hanya defensif, sebagai perlindungan, tidak secara aktif untuk meniadakan pemakaian hukum asing. Seolah-olah suatu rem darurat yang terdapat di dalam sebuah kereta api, sehingga harus digunakan secara hati-hati dan seirit mungkin. Lembaga ketertiban umum ini sebaiknya hanya dipakai sebagai tameng dan tidak sebagai pedang (as a shield not as a sword) untuk menusuk hukum asing. ${ }^{31}$ Ketertiban Umum bersifat relatif . Sifat relatif tersebut karena dipengaruhi oleh faktor-faktor waktu, tempat dan intensitas/ inlandsbeziehungen.

4) Putusan Arbitrase Internasional telah memperoleh eksekuatur dari Ketua Pengadilan Negeri Jakarta Pusat;

Syarat eksekuatur dari Ketua Pengadilan Negeri Jakarta Pusat, merupakan ketentuan baru dalam UU Arbitrase. Karena jika melihat ketentuan dalam Perma, syarat eksekuatur ini diberikan oleh Ketua Mahkamah Agung RI, ${ }^{32}$ melalui Pengadilan Negeri Jakarta Pusat.

Menurut pendapat peneliti, adanya peralihan kewenangan pemberian eksekuatur daei Mahkamah Agung kepada Ketua Pengadilan Negeri Jakarta Pusat adalah untuk alasan distribusi kewenangan, supaya tidak semua permohonan diberikan penetapan eksekusi oleh Mahkamah Agung. Hal ini bertujuan agar terselenggara proses penetapan eksekusi yang singkat dan cepat.

${ }^{29}$ Martin Wolff, Op. Cit., hal. 38.

${ }^{30}$ Sudargo Gautama(e), Op. Cit., hal. 8.

${ }^{31} \mathrm{Hal}$ ini berbeda dengan Konsep Ketertiban Umum yang dianut oleh Perancis-Italia yang menganggap ketertiban umum itu sebagai pedang, "as a sword not as a shield".

${ }^{32}$ Mahkamah Agung RI, Peraturan No. 1 Tahun 1990, Pasal 4 ayat (1). 
Mengenai tata cara permohonan untuk memperoleh eksekuatur, UU Arbitrase tidak mengatur secara eksplisit. Namun hal tersebut dapat disimpulkan dari bunyi Pasal 67 ayat (1) dan ayat (2).

\section{Kelemahan-kelemahan Undang-Undang Arbitrase Dalam mengatur Permasalahan Putusan Arbitrase internasional.}

Jika melihat dari segi substansi UU Arbitrase secara umum, maka dapat dikatakan bahwa UU ini masih mengandung beberapa kelemahan-kelemahan, antara lain: ${ }^{33}$

1) M. Husseyn Umar mengutip pendapat Retnowulan Sutantio mengkritisi tentang komposisi pengaturan Arbitrase dan Alternatif Penyelesaian Sengketa. Dari jumlah 82 pasal, hanya 3 pasal saja yang mengatur tentang Alternatif Penyelesaian Sengketa, dan yang 79 pasal mengatur tentang Arbitrase.

2) Dari segi judul, disebutkan Undang Undang tentang Arbitrase dan Alternatif Penyelesain Sengketa, tetapi dari segi pengaturannya didahulukan tentang Alternatif Penyelesaian Sengketa, baru kemudian pengaturan tentang Arbitrase.

3) Ada pasal-pasal yang sulit dilaksanakan dalam praktek, seperti Pasal 71 yang menyebutkan jangka waktu untuk mengajukan permohonan pembatalan arbitrase adalah 30 hari. Dalam praktek, hal tersebut sulit terpenuhi.

4) Winita E.Kusnandar berpendapat, bahwa dalam UU Arbitrase banyak klausulklausul terselubung. Disamping itu, ada ketentuan yang masih sumir, karena ada beberapa penafsiran, yaitu tentang pembatalan putusan arbitrase yang diatur didalam Bab VII. Ada beberapa pakar yang berpendapat bahwa ketentuan tersebut hanya berlaku untuk arbitrase nasional, tetapi di pihak lain ada juga yang berpendapat bahwa ketentuan tersebut berlaku baik untuk putusan arbitrase nasional maupun internasional.

Selain itu, hasil wawancara peneliti dengan seorang narasumber ${ }^{34}$ mengenai UU Arbitrase, masih terdapat beberapa kelemahan antara lain:

1. UU Arbitrase belum efektif dalam menjamin pelaksanaan putusan arbitrase internasional di Indonesia, karena UU Arbitrase masih mengandung beberapa

${ }^{33}$ Lokakarya yang diselenggarakan di Jakarta atas kerjasama Pusat Pengkajian Hukum dan Mahkamah Agung RI, pada 8 \& 9 Oktober 2002.

${ }^{34}$ Wawancara dengan M. Husseyn Umar di Jakarta pada 14 April 2008. 
kelemahan. Apalagi, ada kemungkinan bahwa implementasi UU ini buruk, misalnya penafsiran konsep ketertiban umum yang sangat sempit.

2. UU Arbitrase belum mengatur permasalahan arbitrase internasional secara komprehensif, oleh karena UU ini masih memiliki beberapa kekurangan. Sedikitnya jumlah permohonan pelaksanaan putusan arbitrase asing di Indonesia bisa jadi merupakan refleksi dari tingkat kepercayaan yang rendah dari pelaku bisnis asing terhadap pengadilan Indonesia. Sehingga pihak asing lebih memilih untuk melaksanakan putusan arbitrase asing di luar negeri.

3. Ada ketentuan-ketentuan tentang arbitrase internasional yang belum terakomodasi di dalam UU Arbitrase, antara lain:

a. Dasar penolakan pelaksanaan putusan arbitrase asing menurut UU Arbitrase lebih sedikit daripada apa yang ditentukan dalam New York Convention. Sehingga beberapa hal seperti masalah due process dan invalid arbitration agreement tidak terakomodasi dalam UU Arbitrase. ${ }^{35}$

b. Tidak diatur definisi dari 'arbitrase internasional'. Padahal banyak terjadi para pihak yang memilih arbitrase BANI dan tempat arbitrase Jakarta adalah pihak asing atau dengan kata lain terdapat unsur asing dalam arbitrase tersebut. Namun karena tidak adanya pengaturan mengenai arbitrase internasional, maka arbitrase yang seperti itu tetap dianggap sebagai arbitrase domestik karena putusannya dikeluarkan di Indonesia.

${ }^{35}$ Dalam hal penolakan putusan arbitrase internasional, Konvensi New York 1958 memberi kesempatan kepada negara peserta konvensi untuk melakukan penolakan terhadap putusan arbitrase internasional, jika memenuhi syarat-syarat seperti yang diatur di dalam Pasal V (1) Konvensi, antara lain:

a) Para pihak dalam perjanjian seperti yang diatur dalam Pasal II, menurut hukum yang berlaku, tidak mempunyai kapasitas, atau perjanjian tersebut tidak sah menurut hukum yang berlaku, atau tidak ada petunjuk bahwa perjanjian tersebut sah, berdasarkan hukum negara dimana putusan itu dibuat;

b) Pihak yang diminta untuk melaksanakan putusan tidak mendapat pemberitahuan yang wajar mengenai penunjukan para arbitrator atau dalam proses arbitrase ia tidak dapat menyampaikan kasusnya;

c) Putusan berkenaan dengan hal yang berbeda atau tidak sesuai dengan hal-hal yang diajukan kepada arbitrator, atau putusan mengandung hal-hal di luar ruang lingkup pengajuan arbitrase;

d) Komposisi dari kekuasaan arbitrase atau prosedur arbitrase tidak sesuai dengan perjanjian yang dibuat oleh para pihak, atau persetujuan itu gagal, jika tidak sesuai dengan hukum negara di tempat arbitrase berlangsung;

e) Putusan belum mempunyai kekuatan mengikat terhadap para pihak, atau telah dikesampingkan atau ditangguhkan oleh otoritas yang berwenang di negara atau berdasarkan hukum negara dimana putusan itu dibuat. 
c. UU Arbitrase mengatur bahwa hubungan arbitrator dengan pihak yang memilihnya adalah hubungan perdata sehingga banyak pihak yang kemudian menggugat arbitratornya karena mereka berpandangan bahwa arbitrator yang telah mereka pilih harus memenangkan mereka.

d. UU Arbitrase bahkan mengatur hal yang menurutnya tidak perlu diatur, seperti misalnya mengenai syarat menjadi arbitrator.

Menurut narasumber lain, masih terdapat kekurangan dengan adanya Pasal 70, 71, dan 72 di dalam UU Arbitrase. Karena, keberadaan ketiga pasal tersebut kurang menjamin pelaksanaan putusan arbitrase internasional di Indonesia. ${ }^{36}$

Menurut penulis, selain kelemahan-kelemahan diatas, ada beberapa kelemahan lain yang berhubungan dengan pengaturan pelaksanaan putusan arbitrase internasional, diantaranya:

1. Pasal 1 mengenai Ketentuan Umum, tidak semua pengertian yang terdapat di dalam UU Arbitrase didefinisikan secara tegas, misalnya tentang putusan arbitrase internasional, ketertiban umum, upaya perlawanan berupa penolakan dan pembatalan putusan.

2. Pasal 67 ayat (1) UU Arbitrase tentang pendaftaran dan penyerahan putusan arbitrase oleh arbitrator atau kuasanya. Pelaksanaan pasal ini mempunyai kendala secara ekonomi, karena arbitrator atau kuasanya dari negara lain harus mendaftarkan putusannya di Pengadilan Negeri Jakarta Pusat. Disamping itu, arbitrator atau kuasanya tidak mempunyai kepentingan baik dari segi ekonomi maupun dari segi hukum. Pada prakteknya, pemenuhan pasal ini sifatnya tidak mengikat.

3. Pasal 70 - 72 tentang pembatalan putusan arbitrase. Pasal tersebut diatur di dalam Bab VII UU Arbitrase. Sampai saat ini masih terdapat perbedaan mengenai interpretasi keberlakuan pasal tersebut, apakah untuk putusan arbitrase nasional atau putusan arbitrase internasional.

4. Tidak diaturnya berapa lama proses pemeriksaan putusan arbitrase internasional untuk mendapatkan penetapan eksekusi dalam UU Arbitrase. Hal ini mengakibatkan, banyaknya putusan arbitrase internasional yang telah didaftarkan, tetapi tidak jelas statusnya. Juni 2008

${ }^{36}$ Wawancara dengan Iswahjudi Karim, SH., LL.M. dari Karimsyah Law Firm di Jakarta 18 


\section{Kesimpulan}

Walaupun Indonesia telah memiliki Undang-undang Arbitrase sejak tahun 1999, namun masih terdapat kendala-kendala dalam pelaksanaan putusan arbitrase internasional di Indonesia. Hal ini disebabkan karena dua hal, antara lain: Pertama, masih terdapatnya beberapa kelemahan-kelemahan dalam UU Arbitrase dalam mengatur permasalahan putusan arbitrase internasional. Hal ini mengakibatkan UU Arbitrase belum efektif dalam menjamin pelaksanaan putusan arbitrase internasional di Indonesia. Apalagi, implementasi Undang-Undang ini kurang tepat, misalnya penafsiran konsep ketertiban umum yang sangat sempit.

Selain itu, UU Arbitrase belum mengatur permasalahan arbitrase internasional secara komprehensif. Ada ketentuan-ketentuan tentang arbitrase intrernasional yang diatur di dalam Konvensi new York 1958, tetapi belum terakomodasi di dalam UU Arbitrase, antara lain : dasar penolakan pelaksanaan putusan arbitrase asing menurut UU Arbitrase lebih sedikit daripada apa yang ditentukan dalam New York Convention. Sehingga beberapa hal seperti masalah due process dan invalid arbitration agreement tidak terakomodasi dalam UU Arbitrase. Hal lain yang belum diatur adalah mengenai pengakuan, pengesampingan/ pembatalan dan penundaan putusan arbitrase internasional.

Tidak diatur definisi dari 'arbitrase internasional'. Padahal banyak terjadi para pihak yang memilih arbitrase BANI dan tempat arbitrase Jakarta adalah pihak asing atau dengan kata lain terdapat unsur asing dalam arbitrase tersebut. Namun karena tidak adanya pengaturan mengenai arbitrase internasional, maka arbitrase yang seperti itu tetap dianggap sebagai arbitrase domestik karena putusannya dikeluarkan di Indonesia. Kelemahan lain yang berhubungan dengan pengaturan pelaksanaan putusan arbitrase internasional, diantaranya: Pasal 67 ayat (1) UU Arbitrase tentang pendaftaran dan penyerahan putusan arbitrase oleh arbiter atau kuasanya. Pelaksanaan pasal ini mempunyai kendala secara ekonomi, karena arbitrator atau kuasanya dari negara lain harus mendaftarkan putusannya di Pengadilan Negeri Jakarta Pusat. Disamping itu, arbitrator atau kuasanya tidak mempunyai kepentingan baik dari segi ekonomi maupun dari segi hukum. Pada prakteknya, pemenuhan pasal ini sifatnya tidak mengikat. Kelemahan lain adalah, tidak diaturnya berapa lama proses pemeriksaan putusan arbitrase internasional untuk mendapatkan penetapan eksekusi dalam UU Arbitrase. 


\section{Daftar Pustaka}

Abdurrasyid, Priyatna. Arbitrase \& Alternatif Penyelesaian Sengketa, Cetakan pertama. Jakarta: PT Fikahati Aneska bekerjasama dengan Badan Arbitrase Nasional Indonesia, 2002.

Adolf, Huala. Arbitrase Komersial Internasional, Jakarta: Rajawali Press, 1991.

. Pelaksanaan Keputusan Badan Arbitrase Komersil Intenasional Menurut Konvensi New York 1958, dalam Varia Peradilan, No.58, Juli 1990. Jakarta: Ikatan Hakim Indonesia, 1990.

Radjagrafindo, 1994.

Arbitrase Komersial Internasional. Jakarta:

. Dasar-dasar Hukum Kontrak Internasional, cetakan kedua, Bandung: Refika Aditama, 2008.

Bidara, O. dan Martin P. Bidara. Hukum Acara Perdata, Cetakan kedua, Jakarta: Pradnya Paramita, 1997.

Black, Henry Campbell. Black's Law Dictionary, Revised fourth edition. St.Paul, Minnesota: West Publishing Co, 1968.

Born, Gary B. International Commercial Arbitration in the United States: Commentary and Materials, Netherlands: Kluwer Law and Taxation Publishers, 1994.

Calamari, John D and Joseph M Perillo. Contracts, Minnesotta: West Publishing Co., 1990.

Cheshire and Norths. Private International Law, Twelfth edition. London: Butterworths, 1992.

Cohn, Ernest et.al. Handbook of Institutional Arbitration in International, Trade. North Holland, Amsterdam: 1977.

Gautama, Sudargo. Arbitrase Dagang Internasional, Cetakan I. Bandung: Alumni, 1979.

. Hukum Perdata Internasional Indonesia, Jilid III Bagian I. Buku ketujuh. Cetakan kedua. Bandung: Alumni, 1981. 
- Soal-soal Aktual Hukum Perdata Internasional, Cetakan I. Bandung: Alumni, 1982.

. Kontrak Dagang Internasional, Bandung: Alumni, 1983.

. Masalah-Masalah Baru Hukum Perdata Internasional, Bandung: PT. Alumni, 1984.

. Himpunan Perundang-undangan Hukum Perdata Internasional Sedunia (Asing - Indonesia), Cetakan II. Bandung: Alumni, 1984.

1984.

. Hukum Perdata Internasional Hukum yang Hidup, Bandung: Alumni,

. Aneka Masalah Hukum Perdata Internasional, Cetakan I. Bandung: Alumni, 1985.

1987.

.Warga Negara dan Orang Asing, Cetakan IV, Bandung: Alumni,

- Perkembangan Arbitrase Dagang Internasional Di Indonesia, Bandung: PT. Eresco, 1989.

- Aneka Masalah Dalam Praktek Pembaharuan Hukum Di Indonesia, Cetakan I. Bandung: PT. Citra Aditya Bakti, 1990.

. Hukum Dagang Dan Arbitrase Internasional, Cetakan I. Bandung: PT. Citra Aditya Bakti, 1991.

. Hukum Perdata Internasional Indonesia, Jilid II bagian 4, buku kelima. Bandung: Alumni, 1995.

. Indonesian Business Law, Cetakan I. Bandung: PT. Citra Aditya Bakti, 1995.

. Aneka Hukum Arbitrase (Ke Arah Hukum Arbitrase Indonesia Yang Baru, Bandung: PT. Citra Aditya Bakti, 1996.

. The Commercial Laws of Indonesia. Cetakan I. Bandung: PT. Citra Aditya Bakti, 1998.

. Hukum Perdata Internasional Indonesia, Cetakan ketiga. Jilid III bagian 2. Buku ke-8. Bandung: Alumni, 1998.

. Undang-Undang Arbitrase Baru 1999, Cetakan I. Bandung: PT. Citra Aditya Bakti, 1999. 
Indonesia dan Konvensi-Konvensi Hukum Perdata Internasional, Cetakan I. Edisi ketiga. Bandung: PT. Alumni, 2002. . Arbitrase Luar Negeri dan Pemakaian Hukum Indonesia, Cetakan I. Bandung: PT. Citra Aditya Bakti, 2004.

Harahap, M.Yahya. Arbitrase, Jakarta: Sinar Grafika, 2004.

Janvan Den Berg, Albert. The New York Arbitration Convention of 1958, Netherlands: Kluwer Law \& Taxation Publishers, 1981.

Rajagukguk, Erman. Arbitrase Dalam Putusan Pengadilan, Jakarta: Chandra Pratama, 2000.

\section{Artikel /Makalah}

Abdurrasyid, Priyatna. "Pengusaha Indonesia Perlu Meningkatkan Minatnya terhadap Arbitrase Dan Alternatif Penyelesaian Sengketa", dalam Jurnal Hukum Bisnis, Vol. 21, Oktober-November 2002:11.

Adolf, Huala. "Improving the Enforcement of International Arbitration Awards In ASEAN Countries", Worksheet on ALSA $10^{\text {th }}$ General Assembly 2009, Hanoi-Vietnam, 14-18 Oktober 2009.

Simanjuntak, Ricardo. "Konflik Yurisdiksi Antara Arbitrase Dan Pengadilan Negeri", dalam Jurnal Hukum Bisnis (Vol. 21, Oktober-November 2002): 85 . 